\title{
Modeling Mediterranean Stock Markets Volatility with Univariate and Multivariate Approaches
}

\author{
SAOUSSAN BOUCHAREB, MOHAMED SALAH CHIADMI, FOUZIA GHAITI \\ Industrial Engineering Department \\ Mohammadia School of Engineering, Mohammed V University \\ Ibn Sina avenue B.P 765, Agdal Rabat 10090 \\ MOROCCO
}

\begin{abstract}
In our study we use the univariate and multivariate GARCH models to analyze the volatility behavior of the daily data of four Mediterranean stock markets (Morocco, Turkey, Spain, and France) spanning the period 2000-2020. We find a strong evidence of persisting of volatility in each of these markets. Results also indicate that both the univariate and the multivariate approaches capture well the ARCH and GARCH effects. We analyze the conditional covariances, and co-volatility spillovers between the Moroccan stock market and the three other Mediterranean stock markets. In order to study co-volatility spillovers, our work is built on the diagonal BEKK model especially the conditional covariances.
\end{abstract}

Key-Words: - GARCH, EGARCH, Multivariate GARCH, Diagonal BEKK, Volatility persistence, Volatility Spillovers

Received: February 27, 2021. Revised: June 28, 2021. Accepted: July 20, 2021. Published: August 12, 2021.

\section{Introduction}

The volatility of the financial markets is an important tool in portfolio management and capital budgeting and an essential element for the choice of risk hedging strategies and the pricing of derivatives securities.

In spite of the abundance of researches in the financial interconnectedness literature, very few have interested to emerging countries, especially the African continent. Academic attention has been on the emerging Asian and Latin American countries. For Morocco, even more rare are the researches which have interested on the behavior of its financial market.

Belcaid and El Ghini (2019) [1] analyze the consequence of economic policy uncertainty (EPU) in the U.S., France, Spain, Germany, the U.K., Italy and China on the long run volatility in the Moroccan stock market. The results indicate that, before the global financial crisis (GFC) of 2008, the connection between the Moroccan stock market and the EPU is generally insignificant for the long run volatility component, specifically for France and Spain. However, after the crisis the study compare results with benchmark GARCH models. They show that nearly all GARCH-MIDAS models with EPU perform significantly in explaining the long run volatility in the Moroccan stock market, especially, the EPU of France, Spain and the US.
Moreover, Belcaid and El Ghini (2019) [2] employed the generalized variance decomposition to evaluate the transmission of volatility spillover effects between the stock markets in Morocco, the U.S., the U.K., France and Germany. Before the GFC, a relative financial connectedness between the European and Moroccan equity markets has been detected. After that, and in spite of a relative increase of spillover effects coming from the U.S. equity market, results show a decline in net spillover effects experienced by Morocco after the GFC.

Ahmed, A. D., \& Huo, R. [3] analyze the dynamic connectedness and volatility transmission mechanisms between Chinese and African stock markets, including Morocco, in recent years. The study uses Bayesian VAR and BEKK GARCH to estimate both price and volatility behaviors of Chinese and 15 selected African stock markets. Results show strong evidence of spillover effects in terms of both price movement and volatility behavior, indicating that Chinese and African stock markets are showing signs of integration.

Furthermore, El Ghini and Saidi [4] applied the Dynamic Conditional Correlation (DCC), the Constant Conditional Correlation (CCC), and the BEKK specifications, with daily data over the period 2002-2012. The authors observe a significant positive correlation between the Moroccan stock market and those of the U.S., the U.K., and France. Furthermore, the results furnish evidence about the 
existence of significant spillover effects from the U.S. and European stock markets to the Moroccan one.

In parallel, Neaime [5] examined financial links between the Middle East and North Africa (including Morocco) stock markets and the more developed financial markets of the US, UK, and France. The author found that the transmission of crisis effects varies according to the trade channel pass through and the financial integration.

Furthermore, Lahmiri (2012) [6] used the EGARCH model and artificial neural networks on the stock markets of Morocco and Saudi Arabia. He shows that trading volume increases the forecasting accuracy of this approach in Morocco. In exact terms, the volatility is over predicted through high volatile periods.

Alagidede and Panagiotidis (2009) [7] analyze the stock returns in Egypt, Kenya, Morocco, Nigeria, South Africa, Tunisia, and Zimbabwe. The random walk hypothesis was studied and rejected. Authors use smooth transition and conditional volatility models to display the dynamics of the first two moments and examine weak form efficiency. The empirical stylized facts of volatility clustering, leptokurtosis, and leverage effect are present in the African data.

Bozma \& Ağirman \& Ahmid (2018) [8] examine the volatility spillovers in Turkey and North Africa (Egypt, Tunisia, and Morocco) by employing VARMA-BEKK GARCH. They display that the Turkish stock market is not influenced by the stock market returns of any of the other countries but it influences the Moroccan stock market.

In summary, more than a few studies have focused on the volatility of the Mediterranean stock markets but it is still a new area of study because of the need for a better understanding of their behavior [9] [10] [11].

Moreover, McAleer (2019a) [12] and McAleer (2019b) [13] highlight the shortcomings of DCC and full BEKK models, and suggest that diagonal BEKK is a more reliable model. However, very few papers have adopted the diagonal BEKK model to estimate volatility spillovers.

Thus, our findings could contribute to improve the efficiency of asset allocation for portfolio managers and individual investors. It is widely recognized that an accurate estimation of stock market volatility is important for meaningful portfolio allocation and risk management [14] [15] [16].

The remainder of this paper is organized as follows. Section 2 contains the problem formulation and section 3 presents the suggested solution. In the end,
Section 4 highlights some concluding remarks and discuss the results of the study.

\section{Problem Formulation}

To analyze financial time-series, researches use often multivariate generalized autoregressive conditional heteroscedasticity (MGARCH) models but their interpretation is not an easy work because of the complication of their structure. In this context, this paper examines the volatility behavior of four Mediterranean stock markets (Morocco, Turkey, Spain, and France), over the period 20002020 , using a range of univariate and multivariate GARCH models.

The purpose of this work is to add another profit of univariate and multivariate GARCH models, especially the BEKK model, whose this work contains an application that relates to the relationship between the four stock markets through the period of interest.

Our choice of the other three Mediterranean countries (France, Spain and Turkey) is justified by their strong economic relations with Morocco. France and Spain remain the primary European trade partners, as well as the primary creditors and foreign investors in Morocco. In addition, Turkey and Morocco also enjoy strong economic relations. Following the free trade agreement promulgated in 2006, bilateral trade relations between the two countries over the period 2006-2019 almost tripled to reach US \$ 2.9 billion.

\section{Problem Solution}

\subsection{Method}

\subsubsection{Univariate GARCH-class Models}

After the important work of Engle [17], the famous volatility model is the GARCH model introduced by Bollerslev [18].

The $\operatorname{GARCH}(p, q)$ model reduces to the $\operatorname{ARCH}(q)$ process when $p=0$. Thus, one of the ARCH parameters must be nonzero $(q>0)$. The GARCH model can be written:

$$
\begin{gathered}
y_{s}=x_{s} \beta+\epsilon_{s} \\
\varepsilon_{s}=\sqrt{h_{s}} e_{s}
\end{gathered}
$$




$$
h_{j}=\omega+\sum_{i=1}^{9} \alpha_{j} \epsilon_{j-i}^{2}+\sum_{j=1}^{p} \gamma_{j} h_{j-j}
$$

Thus, we ca describe the standard $\operatorname{GARCH}(1,1)$ model by:

$$
\begin{gathered}
y_{t}=\mu_{t}+\varepsilon_{t}=\mu_{t} h_{t}^{1 \backslash 2} \eta_{t} ; \quad \eta_{t} \sim i i d(0 ; 1) \\
h_{\mathrm{t}}=\omega+\alpha \varepsilon_{\mathrm{t}-1}^{2}+\gamma \mathrm{h}_{\mathrm{t}-1} ;
\end{gathered}
$$

where, $\mu_{\mathrm{t}}$ denotes the conditional mean and $\mathrm{h}_{\mathrm{t}}$ is the conditional variance with the sufficient conditions $\omega>0, \alpha \geq 0, p \geq 0$ to ensure $h_{t}>0$.

In order to depict the asymmetric effect, Nelson [19] proposed another popular model called the exponential GARCH (EGARCH: exponential generalized autoregressive conditional heteroscedastic).

The EGARCH model contends that the nonnegativity constraints in the standard GARCH model are too restrictive. The GARCH model foistes the nonnegative constraints on the parameters, $\alpha_{\mathrm{i}}$ and $\gamma_{\mathrm{j}}$, while there are no restrictions on these parameters in the EGARCH model. The EGARCH is given as follow:

$$
\begin{gathered}
\log \left(h_{t}\right)=\omega+\alpha\left(\left(\left|\eta_{t-1}\right|-E\left|\eta_{t-1}\right|\right)\right)+\gamma \eta_{t-1} \\
+\beta \log \left(h_{t-1}\right)
\end{gathered}
$$

\subsubsection{Multivariate GARCH-class Models}

Our study concerns the class of multivariate GARCH models coming from the work of Bollerslev, Engle, and Wooldridge [20]. We examine more particularly the following BabaEngle-Kraft-Kroner [21] MGARCH model:

$$
\begin{aligned}
H_{t}=C C^{\prime}+ & \sum_{j=0}^{q} \sum_{k=1}^{k} A_{k j}^{\prime} r_{t-j} r_{t-j}^{\prime} A_{k j} \\
& +\sum_{j=1}^{p} \sum_{k=1}^{k} B_{k j}^{\prime} H_{t-j} B_{k j}
\end{aligned}
$$

where $A_{k j}, B_{k j}$, and $\mathrm{C}$ are $\mathrm{N} \times \mathrm{N}$ parameter matrices, and $\mathrm{C}$ is lower triangular to ensure the positive de definiteness of $\mathrm{H}_{\mathrm{t}}$. Note the BEKK model is covariance stationary if and only if the eigenvalues of

$$
\sum_{j=1}^{q} \sum_{k=1}^{k} A_{k j} \otimes A_{k j}+\sum_{j=1}^{p} \sum_{k=1}^{k} B_{k j} \otimes B_{k j}
$$

are less than one in modulus, with the notation for Kronecker products:

Because of the computational burden resulted from the estimation of a BEKK model, we limit the number of parameters by implementing the following "diagonal BEKK" MGARCH model:

$$
\begin{aligned}
H_{t}=C C^{\prime}+A^{\prime} & r_{t-1} r_{t-1}^{\prime} A \\
& +D E\left[A^{\prime} r_{t-1} r_{t-1}^{\prime} A \mid \widetilde{\Im}_{t-2}\right] D
\end{aligned}
$$

\subsection{Statistics and Data Analysis}

Th variables of interest in this study are the daily returns of four Mediterranean stock markets: Morocco, France, Spain, and Turkey which are computed as first differences of the natural logarithm multiplied by 100 , of the four stock indices. The starting date of the data is January 3, 2000 and series end on June 5, 2020. We have removed the data of those dates when any series has a missing value due to no trading. Thus, all the data are collected for the same dates across the stock markets and there are 4385 observations for each series.

The indexes that constitute the subject of our study are the following:

- MASI index (Moroccan All Shares Index) is a stock index that tracks the performance of all companies listed in the Casablanca Stock Exchange located at Casablanca, Morocco. It is one of the two main indexes at the stock exchange, the other being the MADEX (Moroccan Most Active Shares Index). 
- The IBEX 35 is the benchmark stock market index of the Bolsa de Madrid, Spain's principal stock exchange. Initiated in 1992, IBEX 35 is a market capitalization weighted index comprising the 35 most liquid Spanish stocks traded in the Madrid Stock Exchange General Index and is reviewed twice annually.

- The CAC 40 is a benchmark French stock market index. The index represents a capitalization-weighted measure of the 40 most significant stocks among the 100 largest market caps on the Euronext Paris (formerly the Paris Bourse). It is one of the main national indices of the pan-European stock exchange group Euronext alongside Brussels' BEL20, Lisbon's PSI-20 and Amsterdam's AEX.

- The BIST 100 index is a commonly used abbreviation for the Borsa Istanbul stock exchange, Turkey's main stock exchange. It regulates the activities of the Istanbul Stock Exchange, Istanbul Gold Exchange and Derivatives Exchange of Turkey.

Table 1. Descriptive statistics of returns.

\begin{tabular}{|l|c|c|c|c|}
\hline & Morocco & Turkey & France & Spain \\
\hline Mean & 0.010137 & 0.020208 & 0.001035 & -0.001150 \\
\hline Std. Dev. & 0.351727 & 0.800350 & 0.640836 & 0.655922 \\
\hline Skewness & -0.831564 & -0.313793 & -0.238838 & -0.313567 \\
\hline Kurtosis & 15.98476 & 8.212622 & 10.30712 & 12.41000 \\
\hline $\begin{array}{l}\text { Jarque- } \\
\text { Bera }\end{array}$ & 31303.58 & 5028.370 & 9794.974 & 16239.22 \\
\hline Probability & 0.000000 & 0.000000 & 0.000000 & 0.000000 \\
\hline ADF & $-50.85320 *$ & $-65.03001 *$ & $-67.21441 *$ & $-66.09320 *$ \\
\hline LB (10) & 317.91 & 1094.4 & 29.724 & 12.012 \\
\hline LB2 (10) & 1727.5 & 711.14 & 2004.6 & 1077.6 \\
\hline
\end{tabular}

$*$ denote significance at the $1 \%$ for all return series.

Statistics of daily returns of the four indexes, over the period of interest, are presented in Table 1 . Turkey realized the highest average return $(0.02 \%)$ and Spain had the lowest return (- $0.001 \%)$.
The standard deviation, measuring the unconditional volatility of Mediterranean stock markets, is generally high and ranges from 0.34 (Morocco) to 0.8 (Turkey).

The sample skewness indicate that all the stock return distributions are negatively skewed. The negative skewness of the distribution indicates that an investor may expect frequent small gains and a few large losses.

For the excess kurtosis, results present a highly leptokurtic distribution relative to the normal distribution. The leptokurtic distribution shows that the investment returns may be prone to extreme values on either side. Therefore, an investment whose returns follow a leptokurtic distribution is considered to be risky.

These results are confirmed by the Jarque-Bera (JB) test for normality.

The Ljung-Box test for serial correlation of the 10th order applied to raw and squared returns reject the null hypothesis of no autocorrelation, suggesting the presence of autoregressive parameters in the return generating processes and heteroscedastic variance for all the markets.

In the end, the Augmented Dickey-Fuller (ADF) test furnishes evidence to support the hypothesis of stationarity for all return series at the $1 \%$ level.

We present below, for each country, the plots of daily stock market prices and returns. Figures show that the indexes of the two European countries (France and Spain) have a similar movement but Morocco and Turkey experienced in general a declining trend. The ARCH models are applicable for all return series because of the presence of volatility clustering and leverage effects. 
WSEAS TRANSACTIONS on SYSTEMS and CONTROL

DOI: $10.37394 / 23203.2021 .16 .41$

Figure 1: Close price of Moroccan index (Masi)

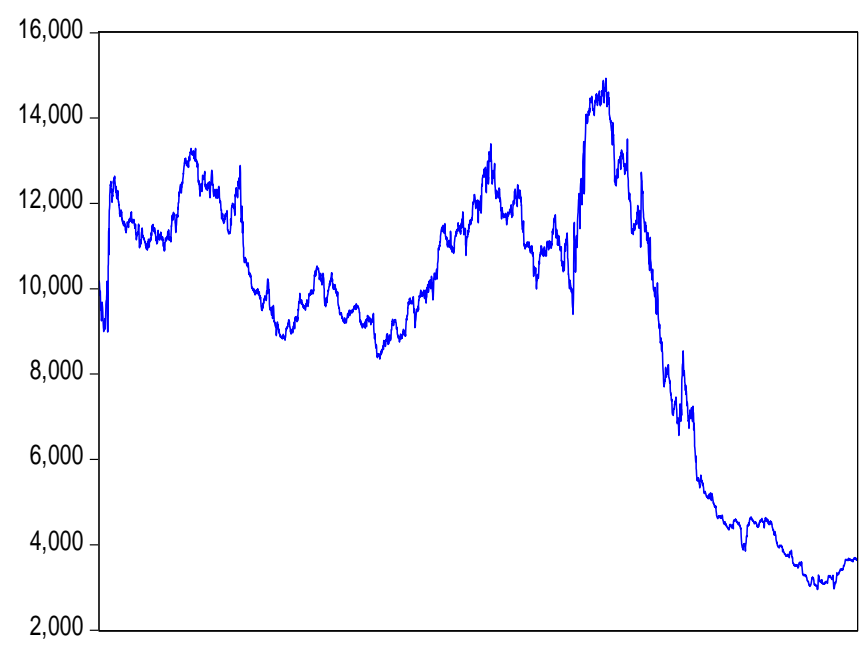

Figure 2: Close price of French index (Cac 40)

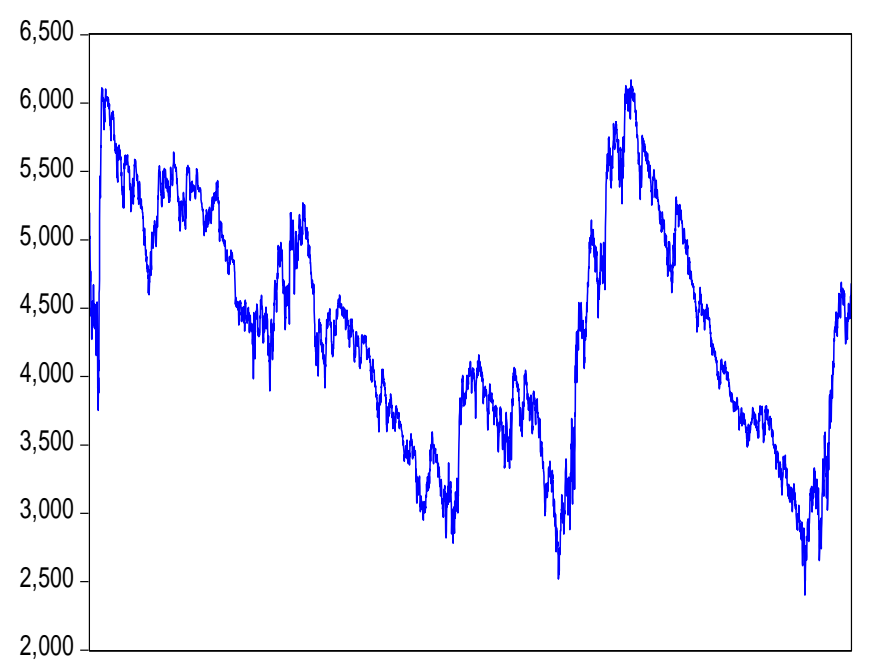

Figure 3: Close price of Spanish index (bex 35)

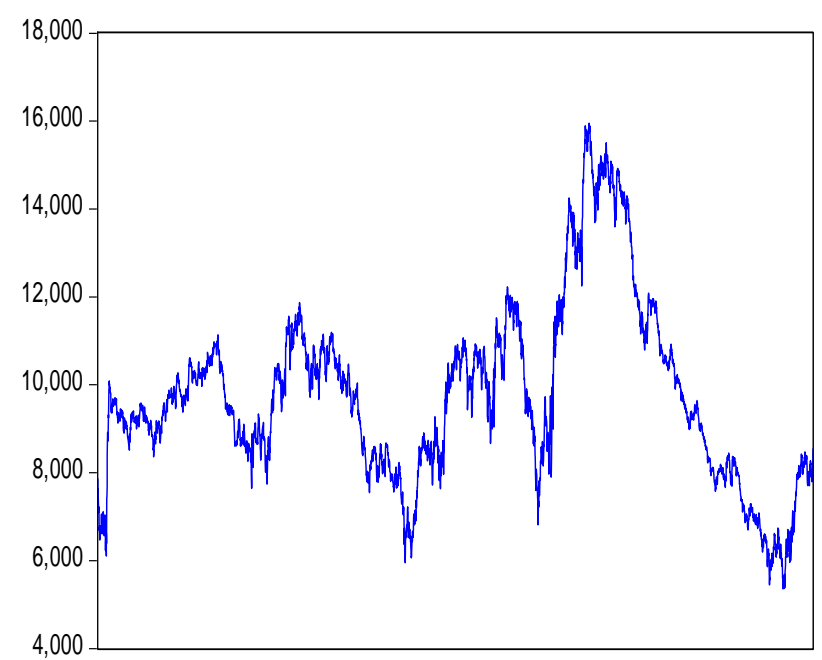

Figure 4: Close price of Turkish index (Bist 100)

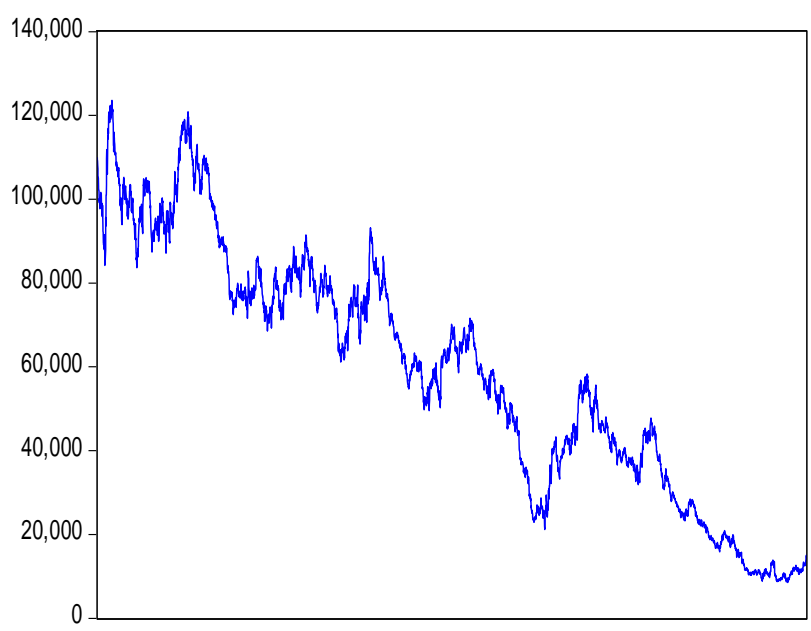


Figure 5: Returns of Moroccan index (Masi)

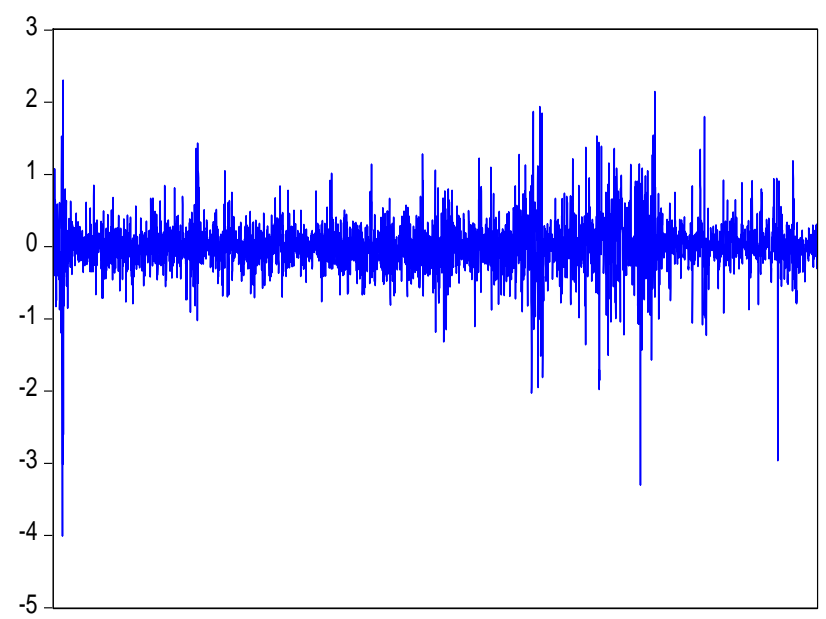

Figure 6: Returns of Spanish index (lbex 35)

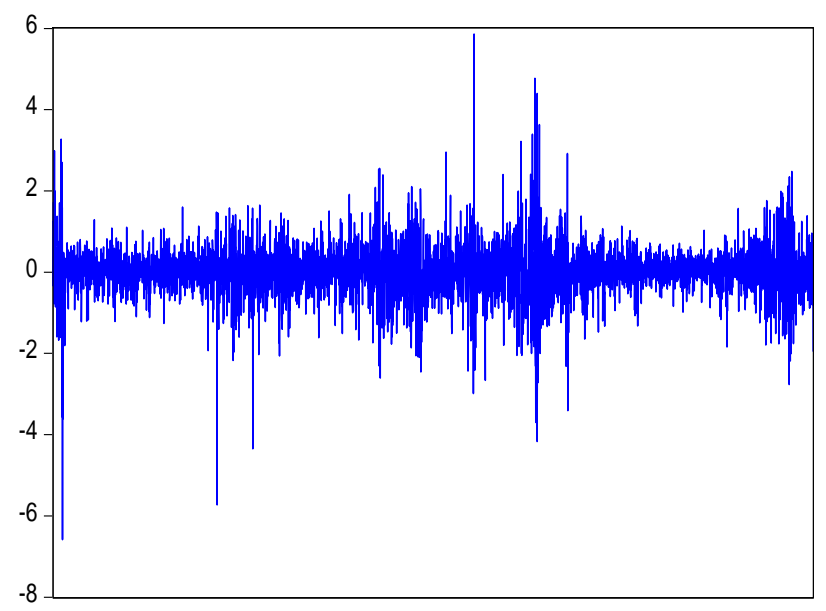

Figure 7: Returns of French index (Cac 40)

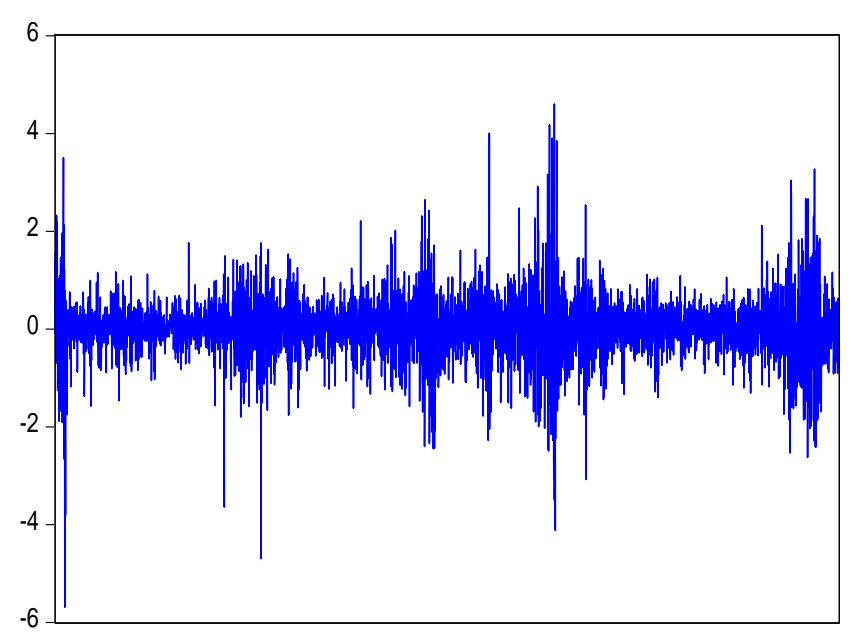

Figure 8: Returns of Turkish index (Bist 100)

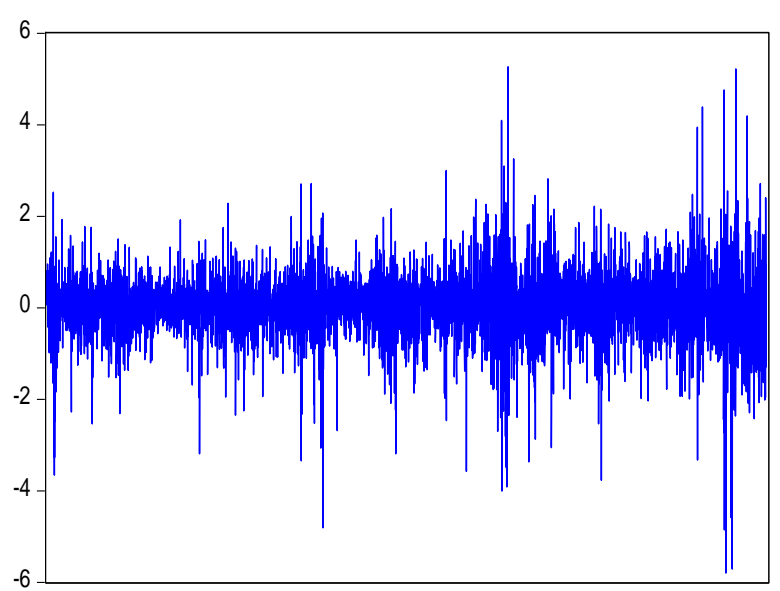

\subsection{Univariate Approach}

The results of the estimation of two univariate models introduced are presented in Section 3.1.1. Starting with the standard $\operatorname{GARCH}(1,1)$, the value of $\alpha$ and $\beta$ are significant and $\alpha$ is a measure of past innovation effect on volatility, and $\beta$ is the impact of past value of volatility on the futur volatility. A high degrees of volatility persistence is detected because the estimates of $\alpha+\beta$ (persistence coefficients) are close to one.

Concerning the EGARCH, coefficient $\gamma$ indicate significant asymmetric effects of standardized shocks implying that there is significant relationship between the four stocks market returns and their conditional volatility. The asymmetric term is positive demonstrating that positive fluctuations have greater influence on volatility more than negative fluctuations of the same magnitude. In other words, the variance increases more after positive residuals than after negative residuals. This simply indicates that investors on the four stock markets are influenced differently to fluctuations depending be it positive or negative in making decisions.

Table 3 shows, also, in his lower part, the results of the diagnostic tests on the squared residuals. The values of $\log (\mathrm{L})$ are, in general, very close to each other across the two univariate models, but for different returns, they have relative large differentials. 
Ljung and Box test shows, for all indices, that we cannot reject null hypothesis of no serial correlations at the $10 \%$ level. The Engle's ARCH test confirms these results. thus, the two models capture ARCH effects in the returns of these four markets.

Table 2. Results of the estimation of the two volatility models.

\begin{tabular}{|c|c|c|c|c|c|c|c|c|}
\hline & \multicolumn{4}{|c|}{ GARCH $(1,1)$} & \multicolumn{4}{|c|}{ EGARCH $(1,1)$} \\
\hline & Masi & Ibex 35 & BIST 100 & CAC 40 & Masi & Ibex 35 & BIST 100 & CAC 40 \\
\hline$\omega$ & $\begin{array}{l}0.009617^{* * *} \\
(7.581077)\end{array}$ & $\begin{array}{l}0.007284 * * * \\
(7.986990)\end{array}$ & $\begin{array}{l}0.012219^{* * *} \\
(7.196699)\end{array}$ & $\begin{array}{l}0.006465^{* * *} \\
(8.393428)\end{array}$ & $\begin{array}{l}-0.368498 * * * \\
(-23.38561)\end{array}$ & $\begin{array}{l}-0.116579^{* * *} \\
(-15.54160)\end{array}$ & $\begin{array}{l}-0.147542 * * * \\
(-15.64411)\end{array}$ & $\begin{array}{l}- \\
0.094264 * * * \\
(-16.61409)\end{array}$ \\
\hline$\alpha$ & $\begin{array}{l}0.275644 * * * \\
(9.593256) \\
\end{array}$ & $\begin{array}{l}0.122123^{* * * *} \\
(20.96512) \\
\end{array}$ & $\begin{array}{l}0.094710^{* * *} \\
(14.37329) \\
\end{array}$ & $\begin{array}{l}0.109794 * * * \\
(16.04281) \\
\end{array}$ & $\begin{array}{l}0.318558 \\
(25.72078) \\
\end{array}$ & $\begin{array}{l}0.139840 * * * \\
(17.54638)\end{array}$ & $\begin{array}{l}0.180199 * * * \\
(15.88544)\end{array}$ & $\begin{array}{l}0.113554 * * * \\
(17.39294)\end{array}$ \\
\hline$\beta$ & $\begin{array}{l}0.673109^{* * *} \\
(28.52753)\end{array}$ & $\begin{array}{l}0.864585^{* * * *} \\
(121.1448) \\
\end{array}$ & $\begin{array}{l}0.889129^{* * *} \\
(126.9708)\end{array}$ & $\begin{array}{l}0.874394 * * * \\
(115.9812) \\
\end{array}$ & $\begin{array}{l}0.944524 \\
(224.5069) \\
\end{array}$ & $\begin{array}{l}0.995928 * * * \\
(635.6505) \\
\end{array}$ & $\begin{array}{l}0.988200^{* * *} \\
(406.8430)\end{array}$ & $\begin{array}{l}1.000791 * * * \\
(908.8315)\end{array}$ \\
\hline$\gamma$ & - & - & - & - & $\begin{array}{l}0.037205^{* * *} \\
(6.178077)\end{array}$ & $\begin{array}{l}0.107960^{* * *} \\
(21.48458)\end{array}$ & $\begin{array}{l}0.048984 * * * \\
(7.274941) \\
\end{array}$ & $\begin{array}{l}0.133938 * * * \\
(21.01230)\end{array}$ \\
\hline $\log (\mathrm{L})$ & -578.5521 & -3587.669 & -4788.126 & -3400.313 & -824.6566 & -3503.949 & -4757.486 & -3291.606 \\
\hline $\mathrm{Q}(10)$ & $\begin{array}{l}21.763 \\
(0.016) \\
\end{array}$ & $\begin{array}{l}12.581 \\
(0.248) \\
\end{array}$ & $\begin{array}{l}5.5419 \\
(0.852) \\
\end{array}$ & $\begin{array}{l}9.4974 \\
(0.486) \\
\end{array}$ & $\begin{array}{l}24.246 \\
(0.007) \\
\end{array}$ & $\begin{array}{l}11.394 \\
(0.328) \\
\end{array}$ & $\begin{array}{l}5.4932 \\
(0.856) \\
\end{array}$ & $\begin{array}{l}12.805 \\
(0.235) \\
\end{array}$ \\
\hline $\mathrm{Q}(20)$ & $\begin{array}{l}24.690 \\
(0.214) \\
\end{array}$ & $\begin{array}{l}22.311 \\
(0.324) \\
\end{array}$ & $\begin{array}{l}12.352 \\
(0.903) \\
\end{array}$ & $\begin{array}{l}16.995 \\
(0.653) \\
\end{array}$ & $\begin{array}{l}27.089 \\
(0.133) \\
\end{array}$ & $\begin{array}{l}20.297 \\
(0.440) \\
\end{array}$ & $\begin{array}{l}10.609 \\
(0.956) \\
\end{array}$ & $\begin{array}{l}18.091 \\
(0.581) \\
\end{array}$ \\
\hline $\mathrm{ARCH}(10)$ & $\begin{array}{l}-0.009598 \\
{[0.9923]}\end{array}$ & $\begin{array}{l}-0.016975 \\
{[0.9865]}\end{array}$ & $\begin{array}{l}-0.915724 \\
{[0.3599]}\end{array}$ & $\begin{array}{l}0.114142 \\
{[0.9091]}\end{array}$ & $\begin{array}{l}-0.008786 \\
{[0.9930]}\end{array}$ & $\begin{array}{l}0.251062 \\
{[0.8018]}\end{array}$ & $\begin{array}{l}-0.404198 \\
{[0.6861]}\end{array}$ & $\begin{array}{l}1.104045 \\
{[0.2696]}\end{array}$ \\
\hline $\mathrm{ARCH}(20)$ & $\begin{array}{l}-0.358063 \\
{[0.7203]}\end{array}$ & $\begin{array}{l}-0.620043 \\
{[0.5353]}\end{array}$ & $\begin{array}{l}0.203617 \\
{[0.8387]}\end{array}$ & $\begin{array}{l}0.350444 \\
{[0.7260]}\end{array}$ & $\begin{array}{l}-0.508409 \\
{[0.6112]}\end{array}$ & $\begin{array}{l}-0.130900 \\
{[0.8959]}\end{array}$ & $\begin{array}{l}-0.275098 \\
{[0.7833]}\end{array}$ & $\begin{array}{l}0.651230 \\
{[0.5149]}\end{array}$ \\
\hline
\end{tabular}

Notes: Numbers in parentheses are z-statistics for $(\alpha, \beta, \gamma)$ and $\mathrm{t}$-statistics for the others parameters. $\mathrm{p}$ Values of the statistics are reported in square brackets.

Table 3. The second moment and log-moment conditions for GARCH and EGARCH

\begin{tabular}{|c|c|c|c|c|}
\hline \multirow{2}{*}{ Returns } & \multicolumn{2}{|c|}{ GARCH } & \multicolumn{2}{c|}{ EGARCH } \\
\cline { 2 - 5 } & Log-moment & Second moment & Log-moment & Second moment \\
\hline Masi & 0.948753 & -0.0228468 & 0.944524 & 0.944524 \\
\hline Ibex 35 & 0.986708 & -0.0058114 & 0.995928 & 0.995928 \\
\hline BIST 100 & 0.983839 & -0.007076 & 0.9882 & 0.9882 \\
\hline CAC 40 & 0.984188 & -0.0069219 & 1.000791 & 1.000791 \\
\hline
\end{tabular}

$\alpha+\beta<1$ is the sufficient condition for the existence of satisfied for all returns as sown in Table 3 , second moment for GARCH [22]. This condition is suggesting the existence of the second moment. The 
value of $|\beta|$ in EGARCH for each return series is less than one, supporting the existence of the second moment [23].

The log-moment condition of $\operatorname{GARCH}(1,1)$ is $\mathrm{E}(\log (\alpha+\beta))<0$ [24]. Table 3 shows also that $\log -$ moment condition is satisfied for all return series. The absolute values of estimates of $\beta$ in EGARCH are less than one, also satisfying the log-moment condition [23].

\subsection{Multivariate Approach}

Table 4. Estimation results of the diagonal Bekk model.

\begin{tabular}{|c|c|c|c|}
\hline & \multicolumn{3}{|c|}{ Diagonal Bekk } \\
\hline & Mor $\mathrm{Tr}$ & Mor Fr & Mor $\mathrm{Sp}$ \\
\hline$\mu 1$ & $\begin{array}{l}0.010111 \\
(0.687286)\end{array}$ & $\begin{array}{l}0.169584 * * * \\
(12.86546)\end{array}$ & $\begin{array}{l}0.000816 \\
(0.053442)\end{array}$ \\
\hline$\mu 2$ & $\begin{array}{l}0.171268^{* * *} \\
(12.43570)\end{array}$ & $\begin{array}{l}-0.031883^{* *} \\
(-2.034950)\end{array}$ & $\begin{array}{l}0.176234 * * * \\
(13.54842)\end{array}$ \\
\hline$\omega 11$ & $\begin{array}{l}0.008762 * * * \\
(7.573298)\end{array}$ & $\begin{array}{l}0.004780^{* * *} \\
(12.01179)\end{array}$ & $\begin{array}{l}0.005344 * * * \\
(7.371984)\end{array}$ \\
\hline$\omega 22$ & $\begin{array}{l}0.005161 * * * \\
(12.59493)\end{array}$ & $\begin{array}{l}0.004835^{* * *} \\
(8.292424)\end{array}$ & $\begin{array}{l}0.004847 * * * \\
(12.18142)\end{array}$ \\
\hline$\alpha 11$ & $\begin{array}{l}0.244388^{* * *} \\
(30.74651)\end{array}$ & $\begin{array}{l}0.345754 * * * \\
(36.28899)\end{array}$ & $\begin{array}{l}0.297618^{* * *} \\
(40.23809)\end{array}$ \\
\hline$\alpha 22$ & $\begin{array}{l}0.367013 * * * \\
(35.75805)\end{array}$ & $\begin{array}{l}0.283965 * * * \\
(34.80285)\end{array}$ & $\begin{array}{l}0.347651 * * * \\
(36.25970)\end{array}$ \\
\hline$\beta 11$ & $\begin{array}{l}0.963398^{* * *} \\
(425.0665)\end{array}$ & $\begin{array}{l}0.916512^{* * * *} \\
(219.3962)\end{array}$ & $\begin{array}{l}0.950017^{* * *} \\
(335.6889)\end{array}$ \\
\hline$\beta 22$ & $\begin{array}{l}0.907096^{* * * *} \\
(206.8584)\end{array}$ & $\begin{array}{l}0.953053^{* * *} \\
(356.2010)\end{array}$ & $\begin{array}{l}0.915639 * * * \\
(217.3916)\end{array}$ \\
\hline Covariance & 0.987861201 & 0.959540075 & 0.991108774 \\
\hline $\begin{array}{l}\text { stationary } \\
\text { condition }\end{array}$ & 0.957521695 & 0.988946142 & 0.959255996 \\
\hline $\log (\mathrm{L})$ & -5620.341 & -4255.095 & -4444.865 \\
\hline $\mathrm{QM}(10)$ & $\begin{array}{l}16.767 \\
{[0.080]}\end{array}$ & $\begin{array}{l}12.147 \\
{[0.275]}\end{array}$ & $\begin{array}{l}9.1977 \\
{[0.513]}\end{array}$ \\
\hline $\mathrm{QM}(20)$ & $\begin{array}{l}25.534 \\
{[0.182]}\end{array}$ & $\begin{array}{l}16.162 \\
{[0.707]}\end{array}$ & $\begin{array}{l}12.741 \\
{[0.888]}\end{array}$ \\
\hline$\overline{\mathrm{QC}(10)}$ & $\begin{array}{l}10.733 \\
{[0.379]}\end{array}$ & $\begin{array}{l}30.648 \\
{[0.001]}\end{array}$ & $\begin{array}{l}19.778 \\
{[0.031]}\end{array}$ \\
\hline$\overline{\mathrm{QC}(20)}$ & $\begin{array}{l}16.824 \\
{[0.664]}\end{array}$ & $\begin{array}{l}34.964 \\
{[0.020]}\end{array}$ & $\begin{array}{l}30.021 \\
{[0.070]}\end{array}$ \\
\hline ARCHM(10) & $\begin{array}{r}0.098771 \\
{[0.9213]}\end{array}$ & $\begin{array}{l}0.009274 \\
{[0.9926]}\end{array}$ & $\begin{array}{l}0.000659 \\
{[0.9995]}\end{array}$ \\
\hline $\operatorname{ARCHM}(20)$ & $\begin{array}{c}-0.438991 \\
{[0.6607]}\end{array}$ & $\begin{array}{l}-0.451041 \\
{[0.6520]}\end{array}$ & $\begin{array}{l}-0.582785 \\
{[0.5601]}\end{array}$ \\
\hline ARCHC(10) & $\begin{array}{l}-0.587995 \\
{[0.5566]}\end{array}$ & $\begin{array}{l}1.158746 \\
{[0.2466]}\end{array}$ & $\begin{array}{l}0.132255 \\
{[0.8948]}\end{array}$ \\
\hline ARCHC(20) & $\begin{array}{l}0.407015 \\
{[0.6840]}\end{array}$ & $\begin{array}{l}0.408901 \\
{[0.6826]}\end{array}$ & $\begin{array}{l}-0.320966 \\
{[0.7483]}\end{array}$ \\
\hline
\end{tabular}


Notes: the numbers in parentheses are z-statistics of the parameter estimates and t-statistics for the others estimates.

* Denotes significance at the $10 \%$ level.

* * Denotes significance at the $5 \%$ level.

$* * *$ Denotes significance at the $1 \%$ level.

Table 4 represent the estimation of diagonal BEKK model and results of the diagnostic tests. The estimates of $\alpha_{\mathrm{ii}}$ and $\beta_{\mathrm{ii}}$ are significant for three pairs of series indicating that the four stock markets have strong ARCH and GARCH effects. The eigenvalues of the matrix $\mathrm{A} \otimes \mathrm{A}+\mathrm{B} \otimes \mathrm{B}\left(\alpha_{\mathrm{ii}}{ }^{2}+\beta_{\mathrm{ii}}{ }^{2}\right.$ for diagonal specification) are smaller than 1 implying stationarity of the covariance process and strong degrees of volatility persistence.

The test of Ljung and Box's show that we cannot reject null hypothesis of no serial correlations at the $10 \%$ level. The F-statistics of Engle's ARCH test confirms these results implying that the model can well capture ARCH and GARCH effects in the returns.

\subsection{Volatility Spillovers}

The diagonal BEKK model can only be used to test for partial covolatility effects [25] [26]. The full BEKK model is essential to report the other two notions of spillover, explicitly, the full volatility and covolatility spillovers.

Because of its statistical precision, we choose to use partial BEKK model and we will only present partial covolatility spillovers.

Most coefficients of the conditional variancecovariance equations are statistically significant implying that the equations capture the volatility and cross volatility for the four stock markets. Precisely, conditional variances-covariances resulted by the Diagonal BEKK model are exposed below.

$$
\begin{aligned}
& \mathrm{h}_{\text {Mor1 }}=0.00477989121906+0.11954616986 * \operatorname{RESID}^{2}(-1)+0.839994150086 * \mathrm{~h}_{\text {Mor1 }}(-1) \\
& \mathrm{h}_{\mathrm{Fr}}=0.00485723269992+0.0806363042743 * \operatorname{RESID}^{2}(-1)+0.908310554189 * \mathrm{~h}_{\mathrm{Fr}}(-1) \\
& \mathrm{h}_{\text {Mor_Fr }}=0.0981822862214 * \operatorname{RESID} 1(-1) * \operatorname{RESID} 2(-1)+0.873484717657 * \mathrm{~h}_{\text {Mor_Fr }}(-1) \\
& \mathrm{h}_{\text {Mor2 }}=0.00513230186642+0.134176869246 * \operatorname{RESID}^{2}(-1)+0.823522820325 * \mathrm{~h}_{\text {Mor2 }}(-1) \\
& \mathrm{h}_{\operatorname{Tr}}=0.00874874843906+0.0598838010852 * \mathrm{RESID}^{2}(-1)+0.928019475165 * \mathrm{~h}_{\operatorname{Tr}}(-1)
\end{aligned}
$$

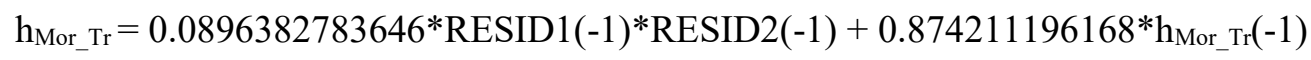

$$
\begin{aligned}
& \mathrm{h}_{\text {Mor3 }}=0.00534410595997+0.0885763734189 * \operatorname{RESID}^{2}(-1)+0.90253313718 * \mathrm{~h}_{\text {Mor }}(-1) \\
& \mathrm{h}_{\mathrm{Sp}}=0.00484673450403+0.120861500474 * \operatorname{RESID}^{2}(-1)+0.838394637945^{*} \mathrm{~h}_{\mathrm{sp}}(-1) \\
& \mathrm{h}_{\text {Mor_Sp }}=0.103467257613 * \operatorname{RESID1(-1)*RESID2(-1)}+0.869872946343 * \mathrm{~h}_{\text {Mor_Sp }}(-1)
\end{aligned}
$$

The empirical results show a strong evidence of GARCH effect and the presence of a weaker ARCH effect. We conclude, also, a statistically significant covariation in shocks, which depends more on its lags than on past errors. Therefore, market shocks are affected by past information which is common to the respective markets.

Own-volatility spillovers (ARCH effects) are positive and significant for all the four markets. The spillover effect is higher for Morocco $(0.13,0.11$, 0.08) and Spain (0.1208) than for France (0.0806) 
and Turkey (0.0598). These coefficients show the volatility persistence for each market in terms of its own past errors.

As for cross-volatility effects, Turkey has the greatest impact on the future volatility of Morocco (0.8742) while the least influential market is Spain (0.8698). The cross-volatility spillovers are higher than own-volatility spillovers in Turkey and France markets contrary to Morocco and Spain.

The lagged own-volatility persistence (GARCH effects) in Morocco (0.83, 0.82, 0.90), Spain (0.83), France (0.90) and Turkey (0.92). These results suggest that all markets derive more of their volatility persistence from within the domestic.

It is an important result here that even though crossvolatility persistence is heterogeneous for the four markets. In addition, the study suggests that the magnitude of cross volatility persistence is not directly associated with geography or economic relations between the countries. It can be due to the level of integration of the market to rest of the world.

Our results confirm, first, the results of El Ghini and Saidi [4] showing a significant positive correlation between the Moroccan stock market and France. Moreover, the results of this study demonstrate evidence about the existence of significant spillover effects from the European stock markets including France and Spain to the Moroccan one. Second, Bozma \& Ağirman \& Ahmid [8] fined that Morocco is the only country in North Africa affected by the stock market of Turkey.

\section{Conclusion}

Our work is an attempt to model the volatility of four Mediterranean stock markets (Morocco, Turkey, France, and Spain) using two different approaches. The first is the univariate approach through the standard $\operatorname{GARCH}(1,1)$ and the EGARCH $(1,1)$ models. The EGARCH model was studied for the reason that the nonnegativity constraints in the standard GARCH model are too restrictive. There are no restrictions on these parameters in the EGARCH model. In the EGARCH model, the conditional variance is an asymmetric function. The results show that the coefficient of asymmetry $(\gamma)$ is significant supporting the use of the EGARCH model.

Consequently, the market reacts to information unequally. Volatility spikes sharply when unexpected positive information reaches the market while remaining unresponsive for a large part to negative information. For investors, this has implications for trading strategies and risk management with respect to equity portfolio risk and returns on the stock exchange.

The results of the univariate approach show also a high degree of volatility persistence. This property shows that the four markets respond to an amount of information flowing into the financial market and reacts to it gradually over time. Consequently, past returns fluctuations can be used as significant information for predicting future returns fluctuations. One implication of this is that shocks to the volatility process tend to have long-lasting effects.

Moreover, the results of the estimation of the diagonal BEKK model indicates also that the four stock markets have strong $\mathrm{ARCH}$ and $\mathrm{GARCH}$ effects and the covariance process is stationary implying a strong degree of volatility persistence.

There exist significant and strong volatility spillover effects for all four markets in conditional variancecovariance equations. The magnitude of the estimates is not homogeneous across markets but remains within a relatively tight range. The impact of lagged covariance on future covariance is found to be positive in all estimations and is extremely high with values often greater than $83 \%$. Thus, the Diagonal BEKK Model presents very large GARCH and relatively low $\mathrm{ARCH}$ effects.

For cross-volatility effects, Turkey has the greatest impact on the future volatility of Morocco while the least influential market is Spain. This unexpected result shows that co-movement across markets is not directly associated with geography or economic relations between the markets because of financial globalization and integration.

Finally, the financial integration may weaken the Moroccan market against external fluctuations. Morocco must now conceive policies not only looking at domestic parameters but also by considering the fact that the country is now highly linked with external markets. Thus, the financial world has changed, and developing countries are not the exception. 
In the end of this paper, we note that this study was only interested in a single multivariate model, namely the diagonal BEKK model. Thus, the analysis can be extended, in a future paper, to other multivariate models in order to report the other two notions of spillover, explicitly, the full volatility and covolatility spillovers.

\section{References:}

[1] Belcaid, Karim \& El Ghini, Ahmed. (2019). U.S., European, Chinese economic policy uncertainty and Moroccan stock market volatility. Journal of Economic Asymmetries.

20. 10.1016/j.jeca.2019.e00128.

[2] Belcaid, Karim \& El Ghini, Ahmed. (2019). Spillover Effects among European, the US and Moroccan Stock Markets before and after the Global Financial Crisis. Journal of African Business. 20.24. 10.1080/15228916.2019.1582266.

[3] Ahmed, Abdullahi \& Huo, Rui. (2018). China-Africa Financial Markets Linkages: Volatility and Interdependence. Journal of Policy Modeling. 40. 10.1016/j.jpolmod.2018.05.002.

[4] El Ghini, Ahmed \& Saidi, Youssef. (2017). Return and volatility spillovers in the Moroccan stock market during the financial crisis. Empirical Economics. 52. 14811504. 10.1007/s00181-016-1110-8.

[5] Neaime, Simon. (2012). The global financial crisis, financial linkages and correlations in returns and volatilities in emerging MENA stock markets. Emerging Markets Review. 13. 268-282.

10.1016/j.ememar.2012.01.006.

[6] Lahmiri, Salim. (2012). An EGARCHBPNN system for estimating and predicting stock market volatility in Morocco and Saudi Arabia: The effect of trading volume. Management Science Letters. 2. 1317-1324. 10.5267/j.ms1.2012.02.007.
[7] Alagidede, Paul \& Panagiotidis, Theodore. (2009). Modelling stock returns in Africa's emerging equity markets. International Review of Financial Analysis. 1-11. 10.1016/j.irfa.2009.02.001.

[8] Bozma, Gurkan \& Ağirman, Ensar \& Ahmid, Almabrok. (2018). The volatility spillovers between Turkey and North Africa (ETM) stock markets: VARMA-BEKK GARCH model.

[9] Chiou, Wan-Jiun. (2006). Who Benefits More from International Diversification?. SSRN Electronic Journal. 10.2139/ssrn.891454.

[10] Driessen, Joost \& Laeven, Luc. (2005). International Portfolio Diversification Benefits: Cross-Country Evidence from a Local Perspective. Journal of Banking \& Finance. $31 . \quad 1693-1712$. 10.1016/j.jbankfin.2006.11.006.

[11] Lagoarde-Segot, Thomas \& Lucey (2007). Capital Market Integration in the Middle East and North Africa. Emerging Markets Finance and Trade. 43. 34-57. 10.2753/REE1540-496X430303.

[12] McAleer, M. (2019a). What They Did Not Tell You about Algebraic (Non-) Existence, Mathematical (IR-) Regularity, and (Non-) Asymptotic Properties of the Dynamic Conditional Correlation (DCC) Model. Journal of Risk and Financial Management, 12(2):61.

[13] McAleer, M. (2019b). What they did not tell you about algebraic (non-) existence, mathematical (ir-) regularity and (non-) asymptotic properties of the full BEKK dynamic conditional covariance model. Journal of Risk and Financial Management, 12(2):66.

[14] Chong, James \& Miffre, J.. (2010). Conditional correlation and volatility in commodity futures and traditional asset markets. J. Altern. Invest.. 12. 61-75. 
[15] Roumpis, Efthymios \& Syriopoulos, Theodore. (2014). Dynamics and risk factors in hedge funds returns: Implications for portfolio construction and performance evaluation. The Journal of Economic Asymmetries. $11 . \quad 58-77$. 10.1016/j.jeca.2014.07.001.

[16] Sadorsky, Perry. (2014). Modeling volatility and correlations between emerging market stock prices and the prices of copper, oil and wheat. Energy Economics.

10.1016/j.eneco.2014.02.014.

[17] Engle, R.F., 1982. Autoregressive conditional heteroskedasticity with estimates of the variance of United Kingdom inflation. Econometrica 50, 9871007.

[18] Bollerslev, T., 1986. Generalized autoregressive conditional heteroskedasticity. J. Econ. 31, 307-327.

[19] Nelson, D.B., 1991. Conditional heteroskedasticity in asset returns: a new approach. Econometrica 59, 347-370.

[20] Bollerslev, T., Engle, R.F. and Wooldridge, J. (1988) A Capital Asset Pricing Model with Time Varying Covariances. Journal of Political Economy, 96, 116-131.

[21] Engle, R.F., Kroner, K.F., 1995. Multivariate simultaneous generalized ARCH. Economet. Theory 11, 122-150.

[22] McAleer, Michael \& Ling, Shiqing. (2003). Asymptotic theory for a new vector ARMA-GARCH model. Econometric Theory. $19.280-310$. $10.1017 / \mathrm{S} 0266466603192092$.

[23] McAleer, Michael \& Chan, Felix \& Marinova, Dora. (2007). An econometric analysis of asymmetric volatility: Theory and application to patents. Journal of Econometrics. $\quad 139.259-284$. 10.1016/j.jeconom.2006.10.014.
[24] Sang-Won Lee and Bruce Hansen, (1994), Asymptotic Theory for the $\operatorname{Garch}(1,1)$ Quasi-Maximum Likelihood Estimator, Econometric Theory, 10, (1), 29-52

[25] Chang, C.-L., Li, Y., and McAleer, M. (2018a). Volatility spillovers between energy and agricultural markets: A critical appraisal of theory and practice. Energies, 11(6):1595.

[26] Chang, C.-L., Liu, C.-P., and McAleer, M. (2019). Volatility spillovers for spot, futures, and etf prices in agriculture and energy. Energy Economics, 81:779-792.

\section{Creative Commons Attribution License 4.0 (Attribution 4.0 International, CC BY 4.0)}

This article is published under the terms of the Creative Commons Attribution License 4.0 https://creativecommons.org/licenses/by/4.0/deed.en US 